\title{
Determination of hepatitis B, C and D prevalence among urban and Amerindian populations from the Eastern Brazilian Amazon: a cross sectional study
}

Livia Melo Villar ${ }^{* *}$ (D, Flavio Augusto Pádua Milagres², Elisabeth Lampe ${ }^{1}$, Helena Medina Cruz', Leticia de Paula Scalioni ${ }^{1}$, Monica de Avelar Figueiredo Mafra Magalhães ${ }^{3}$, Anselmo Rocha Romão ${ }^{3}$,

Renata Gracie ${ }^{3}$ and Vanessa Salete de Paula ${ }^{4}$

\begin{abstract}
Background: This study was conducted to determine the prevalence of HBV, HCV, and HDV in urban populations and Amerindians living in the state of Tocantins (Eastern Amazon).

Methods: A total of 948 individuals were recruited in Tocantinopolis city (Tocantins state) of whom 603 were Amerindians (from 6 tribes) and 345 were non-Amerindians ( 6 urban areas of Tocantinópolis city). Anti-HCV, HBsAg, anti$\mathrm{HBC}$, anti-HBs, anti-HBc IgM, anti-HBe, $\mathrm{HBeAg}$, and anti-delta antibodies were determined using enzyme immunoassay.

Results: HBV cleared infection (both anti-HBC/anti-HBs+), chronic inactive/immune controlled HBV infection (anti-HBC + only), previous HBV vaccination (anti-HBs + only), active HBV infection ( $\mathrm{HBsAg}+$ ), individuals susceptible to HBV, and anti-HCV reactivity were found in 12.9, 1.8, 27.2, 0.5, 57.7, 1.2\% in Amerindians and 12.1, 2.0, 37.1, 0.3, 55.4, 0.3\% in nonAmerindians respectively. Out of 139 anti-HBC reactive individuals, 70 were anti-HBe reactive and none presented $\mathrm{HBeAg}$ or anti-HBC IgM. Anti-HBc prevalence was associated to older age $(p<0.0001)$. Overall anti-Delta prevalence was $0.3 \%$ and regarding anti-HBc reactive individuals, anti-delta prevalence was 3.4 and $0 \%$ in Amerindians and nonAmerindians respectively.

Conclusions: Overall low prevalence of HBV and HCV infection was found in the populations studied, but high HBV and HCV prevalence was observed in Amerindians compared to non-Amerindians suggesting that these individuals have a higher likelihood of acquiring to these infections. Anti-delta antibodies were found among Amerindians from Eastern Amazon suggesting a risk for this population. Of note is that nearly half of Amerindians had no anti-HBs, indicating a need for HBV vaccination campaigns in this population.
\end{abstract}

Keywords: Hepatitis B, Hepatitis C, Hepatitis D, Prevalence, Amerindians, Eastern Amazon, North Brazil

\section{Background}

Hepatitis B, C and D viruses, transmitted predominantly through parenteral routes, represent a considerable threat to public health. Worldwide, approximately 257 million people are chronically infected with hepatitis B virus (HBV), 71 million with chronic hepatitis $\mathrm{C}$ virus

\footnotetext{
* Correspondence: liviafiocruz@gmail.com; Ivillar@ioc.fiocruz.br

'Laboratory of Viral Hepatitis, Oswaldo Cruz Institute, FIOCRUZ, Helio and

Peggy Pereira Pavillion - Ground Floor - Room B09, FIOCRUZ Av. Brasil, 4365

- Manguinhos -, Rio de Janeiro, RJ 210360-040, Brazil

Full list of author information is available at the end of the article
}

(HCV) and 15 million with HBV and hepatitis D virus (HDV) [1-3].

Multicenter studies conducted in several regions of Brazil have demonstrated seroprevalence rates of anti-HBc (HBV past exposure) of $11.6 \%$ and anti-HCV of $3.22 \%$ in individuals aged 10 to 69 years old from North region of Brazil $[4,5]$. In the period spanning 1999 to 2016, approximately 561,000 confirmed cases of viral hepatitis were reported to health authorities in Brazil. Of these, 212.031 (37,8\%) hepatitis B, 182.389

(C) The Author(s). 2018 Open Access This article is distributed under the terms of the Creative Commons Attribution 4.0 International License (http://creativecommons.org/licenses/by/4.0/), which permits unrestricted use, distribution, and 
(32,5\%) hepatitis C and 3.791 (0,7\%) hepatitis D cases were identified [6].

HBV, HCV and HDV prevalence varies considerably according to geographical region of the country, where the highest HCV prevalence (3.22\%) is observed in the North region [5]. The highest rates of HBV carriers and more than 70\% of reported HDV cases are also observed in the Amazon Region located in the North of the country [6, 7]. HDV infection is also common in acute hepatitis B cases (29\%) and fulminant hepatitis cases (74\%) in the North of Brazil [8].

Some specific groups, like Amerindians, people who use drugs, beauty professionals, and military personnel are at higher risk of viral hepatitis acquisition [7, 9-12]. In 2010 the Brazilian census estimated the population of Amerindians at 896,917 individuals, corresponding to $0.47 \%$ of the general population with nearly half of them living in the Northern region of the country [13]. HBsAg prevalence varies from 0 to $20.6 \%$, Anti-HDV from 0 to $7.7 \%$ [7] and anti-HCV from 1.4 to $1.6 \%$ [14] in the Northern Amerindian population.

Viral hepatitis is higher in the Northern areas where many Amerindians live, and even within this region prevalence varies between different areas. Most prevalence studies of viral hepatitis from the North of Brazil were conducted in Western Amazon [15-20] and there is a gap in the literature in terms of geographical variations. As a result, this information is needed to develop targeted screening programs.

This study was conducted to estimate the prevalence rates of HBV, HCV and HDV markers between Amerindians and the general population residing in the state of Tocantins (Eastern Amazon) located in the Northern region of Brazil.

\section{Methods}

A cross-sectional survey regarding hepatitis $\mathrm{B}, \mathrm{C}$ and $\mathrm{D}$ prevalence was conducted using a non-probability sampling method among Amerindians and non-Amerindians living in Eastern Amazon. Consecutive sampling was used in which every subject meeting the criteria of inclusion is selected until the required sample size is achieved in this setting. The North Region of Brazil is comprised of seven States (Acre, Amapá, Amazonas, Pará, Rondônia, Roraima and Tocantins) that, together with Mato Grosso and Maranhão States form the Brazilian Amazon. The West Amazon region comprises the states of Amazonas, Acre, Rondônia and Roraima. The East Amazon is comprised of the states of Maranhão, Pará, Amapá, Mato Grosso and Tocantins. The study was carried out from June 2011 to June 2017 and samples were collected from 6 tribes of Amerindians and 6 urban areas of Tocantinópolis city in June 2011.
Eligibility criteria for participation of this study were: residence in the area and the provision of informed consent. Exclusion criteria were: confusion at the time of recruitment and disagreement with the terms of the informed consent.

\section{Blood sampling and viral hepatitis detection}

Each participant donated a blood sample $(5 \mathrm{~mL})$ by venipuncture using a vacutainer device. The sample was allowed to clot to separate the serum for analysis and was stored at $-20{ }^{\circ} \mathrm{C}$ until analysis.

Serum samples were tested for $\mathrm{HBsAg}$, anti-HBc, anti-HBs, anti-HCV, using commercial enzyme immunoassay (ELISA) kits (Diasorin, Pomezia, Italy), according to the manufacturer's guidelines. HBsAg or Anti-HBc reactive samples were also assayed for anti-HBc IgM and anti-delta antibodies using ELISA kit (Diasorin), and anti-HBe and $\mathrm{HBeAg}$ using eletrochemiluminescence assay (ECLIA) (Roche, USA).

Samples found to be negative on preliminary screening were considered seronegative. Samples that initially tested borderline or positive were retested using ELISA to confirm the results. Indeterminate samples were excluded from the analysis.

Anti-HCV reactive samples were submitted to real time PCR (Cobas Taqman HCV 2.0, Roche, USA), which has a dynamic range of linear quantification of 20 to $1.7 \times 10^{8} \mathrm{IU} / \mathrm{mL}$. HBsAg-reactive samples were submitted to real time PCR (Cobas Taqman HBV Test, Roche, USA), which has a dynamic range of linear quantification of 29 to $1.1 \times 10^{8} \mathrm{IU} / \mathrm{mL}$.

\section{Data collection and analysis}

Age, gender and residential location data were obtained from each participant and entered along with serological results into (Microsoft Excel) data spreadsheets.

Prevalence was calculated for HBV, HCV and HDV markers in the studied population. Descriptive statistics were generated for the data. Chi square test for independence and exact Fisher's tests were used to compare categorical variables according to anti-HBc status. A $p$-value $<0.05$ was considered statistically significant. All calculations were performed using the Statistical Package for the Social Sciences (SPSS for Windows, release 20.0; SPSS, Chicago, IL, USA).

The spatial representation of HBV markers analyzed was based on cartography of the digital mesh of the 2010 census, [13] and data of HBV markers according localities of the municipality of Tocantinópolis in the state of Tocantins. For the adaptation of the analyzed locations to the census tracts, the National Register of Addresses for Statistical Purposes of the IBGE was used [13]. Thematic maps of HBV markers were created using 
Table 1 Hepatitis B and C virus markers among individuals from Amerindian tribes and urban areas of Tocantinopolis city $(n=948)$

\begin{tabular}{|c|c|c|c|c|c|c|c|}
\hline & $\begin{array}{l}\text { Number } \\
\text { Tested }\end{array}$ & $\begin{array}{l}\text { HBsAg - anti-HBC } \\
+ \text { anti-HBs + (HBV } \\
\text { cleared infection) }\end{array}$ & $\begin{array}{l}\mathrm{HBsAg} \text { - anti-HBC + } \\
\text { anti-HBs - (Chronic } \\
\text { inactive/immune } \\
\text { controlled HBV infection) }\end{array}$ & $\begin{array}{l}\mathrm{HBsAg}-\text { anti-HBC - } \\
\text { anti-HBs + (HBV } \\
\text { Vaccination group) }\end{array}$ & $\begin{array}{l}\text { HBsAg + anti- } \\
\text { HBs - (HBV } \\
\text { active } \\
\text { infection) }\end{array}$ & $\begin{array}{l}\text { HBsAg - anti-HBC - } \\
\text { anti-HBs - (HBV } \\
\text { susceptible } \\
\text { individuals) }\end{array}$ & anti-HCV + \\
\hline $\begin{array}{l}\text { Total population } \\
\text { studied }\end{array}$ & 948 (100\%) & $120(12.6 \%)$ & $18(1.9 \%)$ & $268(28.3 \%)$ & $4(0.4 \%)$ & $538(56.7 \%)$ & $8(0.8 \%)$ \\
\hline \multicolumn{8}{|l|}{ Sex } \\
\hline Female & $505(53.3 \%)$ & $56(11.1 \%)$ & $9(1.8 \%)$ & $143(28.3 \%)$ & $2(0.4 \%)$ & $296(58.6 \%)$ & $1(0.2 \%)$ \\
\hline Male & $443(46.7 \%)$ & $64(14.4 \%)$ & $9(2.0 \%)$ & $125(28.2 \%)$ & $2(0.4 \%)$ & $242(54.6 \%)$ & $7(1.6 \%)$ \\
\hline \multicolumn{8}{|l|}{ Age group (years) } \\
\hline $0-20$ & $438(46.2 \%)$ & $9(2.0 \%)$ & $3(0.7 \%)$ & $166(0.4 \%)$ & $2(0.4 \%)$ & $258(58.9 \%)$ & $0(0.0 \%)$ \\
\hline $21-40$ & $277(29.2 \%)$ & $31(11.2 \%)$ & $0(0.0 \%)$ & $88(31.7 \%)$ & $1(0.4 \%)$ & $157(56.6 \%)$ & $4(1.4 \%)$ \\
\hline $41-60$ & $142(14.9 \%)$ & $49(34.5 \%)$ & $5(3.5 \%)$ & $9(6.3 \%)$ & $1(0.7 \%)$ & $78(54.9 \%)$ & $3(2.1 \%)$ \\
\hline$>60$ & $91(9.6 \%)$ & $31(34.1 \%)$ & $10(11.0 \%)$ & $5(5.5 \%)$ & $0(0.0 \%)$ & 45 (49.4\%) & $1(1.1 \%)$ \\
\hline \multicolumn{8}{|l|}{ Location } \\
\hline Amerindian tribes & $603(63.6 \%)$ & 78 (12.9\%) & $11(1.8 \%)$ & $164(27.2 \%)$ & $3(0.5 \%)$ & $348(57.7 \%)$ & $7(1.2 \%)$ \\
\hline $\begin{array}{l}\text { Prata } \\
\text { village }\end{array}$ & $53(5.6 \%)$ & $2(3.8 \%)$ & $0(0.0 \%)$ & $24(45.3 \%)$ & $0(0.0 \%)$ & $27(50.9 \%)$ & $0(0.0 \%)$ \\
\hline $\begin{array}{l}\text { Girassol } \\
\text { village }\end{array}$ & 89 (9.4\%) & $16(17.9 \%)$ & $0(0.0 \%)$ & $14(15.7 \%)$ & $1(1.1 \%)$ & $58(65.2 \%)$ & $1(1.1 \%)$ \\
\hline $\begin{array}{l}\text { Mariazinha } \\
\text { village }\end{array}$ & $206(21.7 \%)$ & $29(14.1 \%)$ & $1(0.5 \%)$ & $51(24.7 \%)$ & $1(0.5 \%)$ & $124(60.2 \%)$ & $3(1.4 \%)$ \\
\hline $\begin{array}{l}\text { Riachinho } \\
\text { village }\end{array}$ & $18(1.9 \%)$ & $3(16.6 \%)$ & $0(0.0 \%)$ & $6(33.3 \%)$ & $0(0.0 \%)$ & $9(50.0 \%)$ & $0(0.0 \%)$ \\
\hline $\begin{array}{l}\text { Serrinha } \\
\text { village }\end{array}$ & $66(7.0 \%)$ & $1(1.5 \%)$ & $0(0.0 \%)$ & 17 (25.7\%) & $0(0.0 \%)$ & 48 (72.7\%) & $1(1.5 \%)$ \\
\hline $\begin{array}{l}\text { Folha Grossa } \\
\text { village }\end{array}$ & 171 (18.0\%) & $27(15.8 \%)$ & 10 (5.8\%) & $52(30.4 \%)$ & $1(0.6 \%)$ & $82(0.5 \%)$ & $2(1.2 \%)$ \\
\hline $\begin{array}{l}\text { Non-Amerindian } \\
\text { (Urban areas) }\end{array}$ & 345 (36.4\%) & $42(12.2 \%)$ & 7 (2.0\%) & $128(37.1 \%)$ & $1(0.3 \%)$ & 191 (55.4\%) & $1(0.3 \%)$ \\
\hline $\begin{array}{l}\text { Cacau } \\
\text { urban area }\end{array}$ & $60\left(6.3 \%{ }^{\prime}\right)$ & $3(5.0 \%)$ & $1(1.7 \%)$ & 12 (20.0\%) & $0(0.0 \%)$ & 44 (73.3\%) & $1(1.7 \%)$ \\
\hline $\begin{array}{l}\text { Mumbuco } \\
\text { urban area }\end{array}$ & 81 (8.5\%) & 9 (11.1\%) & $1(1.2 \%)$ & 32 (39.5\%) & $0(0.0 \%)$ & $39(48.1 \%)$ & $0(0.0 \%)$ \\
\hline $\begin{array}{l}\text { BelaVista } \\
\text { urban area }\end{array}$ & $10(1.0 \%)$ & $2(20.0 \%)$ & $0(0.0 \%)$ & $2(20.0 \%)$ & $0(0.0 \%)$ & $6(60.0 \%)$ & $0(0.0 \%)$ \\
\hline $\begin{array}{l}\text { Urban area } \\
\text { block } 18\end{array}$ & 84 (8.9\%) & $10(11.2 \%)$ & $3(3.6 \%)$ & 25 (29.7\%) & $1(1.2 \%)$ & 45 (53.6\%) & $0(0.0 \%)$ \\
\hline $\begin{array}{l}\text { Urban area } \\
\text { block } 22\end{array}$ & 61 (6.4\%) & $5(8.2 \%)$ & $2(3.3 \%)$ & $21(34.4 \%)$ & $0(0.0 \%)$ & $33(54.1 \%)$ & $0(0.0 \%)$ \\
\hline $\begin{array}{l}\text { Tocantinópolis } \\
\text { Downtown }\end{array}$ & 49 (5.2\%) & 13 (26.5\%) & $0(0.0 \%)$ & $36(73.5 \%)$ & $0(0.0 \%)$ & $24(49.0 \%)$ & $0(0.0 \%)$ \\
\hline
\end{tabular}

the Geographic Information System (GIS) ArcGis version 10.4 .

\section{Ethical consideration}

The study project was reviewed and approved by Fiocruz ethics Committee and Brazilian National Ethics Council, Brazilian Indian Foundation and local tribe leaders. For this study, authorization was solicited and obtained from the Indians' authorities at the national, regional, and local levels.
Respondents were assured about confidentiality, that their participation was voluntary and that they had full rights to withdraw from the study at any time. All participants were given a verbal explanation of the objectives and methodology of the research and were included in the study only after obtaining written signed informed consent. Parent or guardian gave written signed informed consent on behalf of any participants under the age of 18. All individuals who tested positive were sent to public health clinics to receive treatment. 


\section{Results}

In the present study, 948 individuals were included aging 0 to 90 years, 569 were Amerindians and 379 were non-Amerindians. Most of them were females (53.3\%) and mean age of individuals was $27.8 \pm 20.6$ years. The socio-demographic characteristics of the 948 individuals included in this study are shown in Table 1.

Markers of $\mathrm{HBsAg}$, anti-HBc and anti-HBs were detected in 4,138 , and 388 individuals giving an overall prevalence of $0.4,14.5,40.9 \%$, respectively. Among the $4 \mathrm{HBsAg}$ reactive individuals, none of them presented $\mathrm{HBeAg}$ or anti-HBc IgM and only one presented detectable anti-HBc, anti-HBe and HBV DNA (viral load of $6469 \mathrm{IU} / \mathrm{mL}$ ). Of the 138 anti-HBc-reactive individuals, 70 were anti-HBe-reactive and none presented $\mathrm{HBeAg}$ or anti-HBc IgM. Anti-HBc prevalence was positively associated with older age $(p<0.0001)$ in bivariate analyses (Table 2).

HBV cleared infection (both anti-HBc/anti-HBs+), chronic inactive/immune controlled HBV infection (anti-HBc + only), previous $\mathrm{HBV}$ vaccination (anti-HBs + only), HBV active infection (HBsAg+), individuals susceptible to $\mathrm{HBV}$, and anti-HCV reactivity were found in 12.9, 1.8, 27.2, 0.5, 57.7, 1.2\% in Amerindians and 12.1, 2.0, $37.1,0.3,55.4,0.3 \%$ in non-Amerindians respectively.

Among HBV immune individuals $(n=388), 268$ were previously vaccinated (only anti-HBs detected) and 120 had had a previous HBV infection (Table 1). HBV immunity was high in males and individuals aging 21 to 40 years old, but evidence of HBV vaccination (only anti-HBs detected) was more frequent in Amerindian populations, females and those less than 20 years of age.

The municipalities with the highest HBV-immune individuals were from Folha Grossa and Mariazinha villages while the lowest number of HBV-immune subjects

Table 2 Bivariate analysis of demographic factors associated to anti-HBc prevalence in the population studied

\begin{tabular}{llll}
\hline Variable & \multicolumn{2}{l}{ Total Anti-HBC } & $\begin{array}{l}\text { Bivariate } \\
\text { analysis } P \text { Value }\end{array}$ \\
\cline { 2 - 3 } & $\begin{array}{l}\text { Reactive } \\
n=138(\%)\end{array}$ & $\begin{array}{l}\text { Non reactive } \\
n=810(\%)\end{array}$ & \\
\hline Age (years) & & & \\
$0-20$ & $12(8.7)$ & $426(52.6)$ & $<0.0001$ \\
$21-40$ & $31(22.5)$ & $246(30.4)$ & \\
$41-60$ & $54(39.1)$ & $88(10.9)$ & \\
$>60$ & $41(29.7)$ & $50(6.1)$ & \\
Gender & & & \\
Male & $73(52.9)$ & $370(45.6)$ & 0.11 \\
Female & $65(47.1)$ & $440(54.4)$ & \\
Location & & & \\
Ameridian & $89(64.5)$ & $514(63.5)$ & 0.84 \\
Non Ameridian & $49(35.5)$ & $296(36.5)$ & \\
\hline
\end{tabular}

were seen in Serrinha, Prata, Riachinho and Cacau villages (Figs. 1 and 2).

Anti-Delta was not detected in HBsAg-reactive samples, but it was present in 3 anti-HBc -reactive samples, giving an overall prevalence of $0.3 \%$. Considering these anti-HBc-reactive samples, prevalence of anti-delta was 3.4 and $0 \%$ in Amerindians and non-Amerindians respectively. All were male, more than 60 years of age, 2 were from Folha Grossa village and 1 was from Mariazinha village.

Anti-HCV was detected in 8 individuals (7 Amerindian and 1 non-Amerindian), resulting in a prevalence of 1.2 and $0.3 \%$ in Amerindians and non-Amerindians respectively and an overall prevalence of $0.8 \%$. High prevalence was observed in males (87.5\%) and $50 \%$ of individuals aged between 21 to 40 years. HCV RNA was detected in one sample (viral load of $3552 \mathrm{UI} / \mathrm{mL}$ ).

\section{Discussion}

Parenterally transmitted hepatitis viruses are important threats to public health with Amerindians being potentially more exposed to these infections due to social and cultural habits. Viral hepatitis prevalence has been widely investigated in the Western Amazonian region of Brazil [15-21], but few data are available for the Eastern Amazon region [22, 23], principally in the state of Tocantins. In the present study, new data about HBV, $\mathrm{HCV}$ and HDV prevalence were obtained from Eastern Amazon and low prevalence of $\mathrm{HBsAg}$, anti-HCV and anti-delta was observed in these individuals, showing a low risk of transmission of these viruses in this region.

Overall HBsAg prevalence was $0.4 \%$, lower than reported in a previous study from Eastern Amazon (2.88\%) [23], and hemodialysis individuals from Tocantins state (4\%) [24]. HBsAg prevalence was slightly higher in Amerindians (0.3\%) when compared to non-Amerindians $(0.1 \%)$, but this prevalence is still lower than observed in Amerindians from other localities of the Amazon Region, such as the states of Xingu, Pará and Acre, where prevalence varies from 3.3 to $14.4 \%[7,17,22,25]$. Some authors reported that sociocultural factors such as population density, scarification, tattoos and sexual activity represent important factors in the transmission of $\operatorname{HBV}[8,26,27]$. It is possible that the infrequency of these factors among Amerindians from Tocantins may explain their low HBV prevalence compared to other Amerindians from Amazon.

HBV cleared infection was observed in $14.5 \%$ of individuals and it was higher among Amerindians and individuals more than 40 years of age. Anti-HBc prevalence varies from 40.7 to $84.7 \%$ among Amerindians from Eastern Amazon region $[7,22,23]$ and 19.7 to $95.7 \%$ among Amerindians from Western Brazilian Amazon [7, 17]. Anti-HBc prevalence was high among older individuals, in concordance 


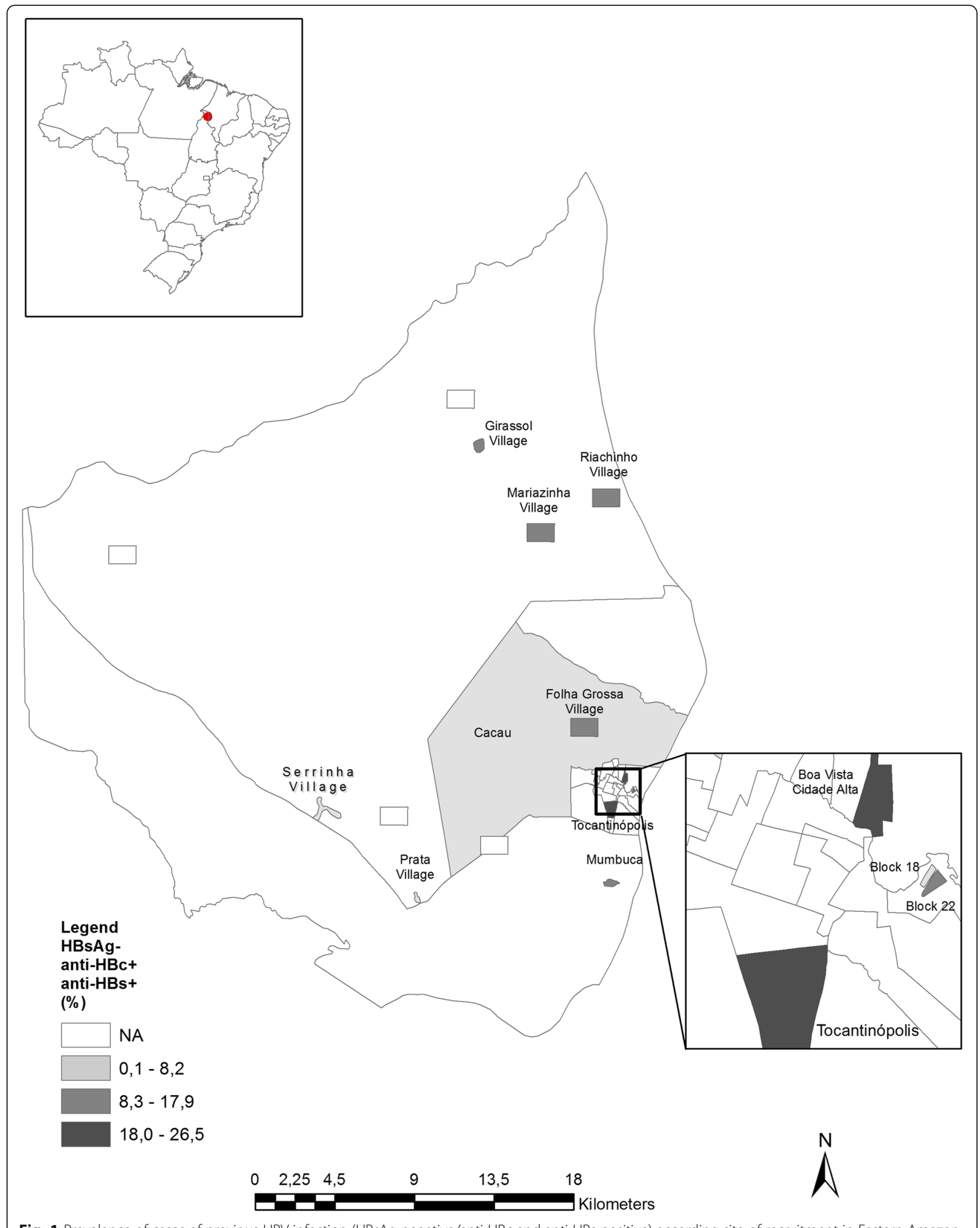

Fig. 1 Prevalence of cases of previous HBV infection (HBsAg negative/anti-HBc and anti-HBs positive) according site of recruitment in Eastern Amazon 


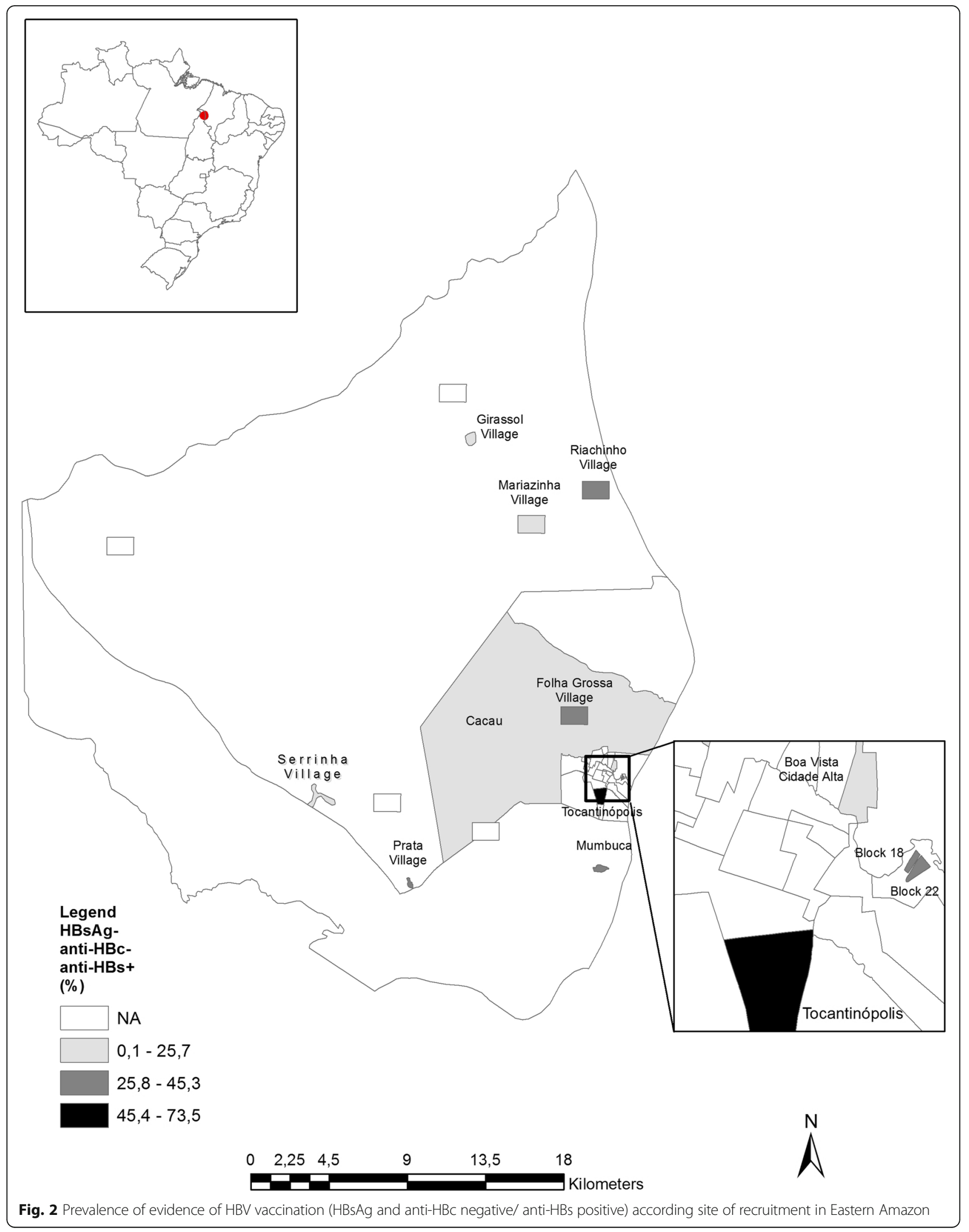


with previous studies among non-Amerindians from Amazon region [16, 21, 23].

In the present study, $56.7 \%$ of subjects were susceptible to HBV infection and less than $50 \%$ were HBV immune, indicating that most individuals are not protected against $\mathrm{HBV}$ infection. Although Amerindians are a target group for HBV vaccination, only $27.2 \%$ of Amerindians demonstrated isolated anti-HBs reactivity, less than that observed among Amerindians from the Southern (71.0\%) and Northern (39.6\%) regions of Brazil $[22,28]$. It is likely that the low anti-HBs reactivity could be due to poor knowledge about HBV vaccination as previously demonstrated in other groups from the Northern region [29].

Anti-HBs reactivity was irregular among distinct sites of collection where a high prevalence of HBV-immune individuals was found in downtown Tocantinopolis, Folha Grossa and Mariazinha village. This could also be explained by access to health clinics, where high HBV vaccination coverage was found in urban areas. At the time of recruitment (2011), The Brazilian Immunization Program recommended $\mathrm{HBV}$ vaccination for all Amerindians and for non-Amerindians newborns and children and adolescents up to 19 years of age. Additionally, the vaccination was also recommended to those at higher risk of acquiring infection such as people who use drug, health professionals, prisoners and other groups [30, 31]. In the present study, high HBV vaccine coverage was found among people aged 0-20 since $\mathrm{HBV}$ vaccination was implemented for this demographic.

Overall an anti-HCV prevalence of $0.8 \%$ was observed in individuals from Tocantinópolis city, lower than that observed in studies of the general population from the Eastern Amazon Region (2.2 to $5.76 \%)[23,32,33]$ or hemodialysis individuals from Tocantins state (13\%) [24]. However, anti-HCV prevalence was high in Amerindians (1.2\%) compared to non-Amerindians $(0.3 \%)$ in concordance with a previous study from the Northern region (1.4\%) [14].

Some studies have demonstrated that sharing cutting instruments among relatives and/or neighbors is a common habit in individuals from the Amazon region [34, 35]. These cultural habits could increase the risk of transmission of parenterally acquired viruses, such as, HCV. In addition, low knowledge about hepatitis transmission [29] and low access to treatment service could contribute to this high prevalence.

Overall anti-delta prevalence was $0.3 \%$ and all of these individuals were Amerindians, giving a prevalence of $3.4 \%$ in this group. According to the Brazilian Health Ministry, 10 confirmed cases of hepatitis D were found in Tocantins from 1999 to 2016 giving a prevalence of $0.3 \%$ in Brazil [6]. Previous studies did not find anti-delta antibodies in Amerindians from the Eastern Amazon Region, [22, 25] while an anti-delta prevalence of 2.9 to $7.3 \%$ was observed in the Western Amazon Region [15, 17, 21].

Of the residents in the northern Area of Tocantins state, approximately $4.4 \%$ are reported to be Amerindian, with $81 \%$ of the population living in urban areas [36]. In the present study, $60 \%$ of participants were Amerindian and $64 \%$ reported living rurally/in villages. The main purpose of this study is to provide new insights regarding hepatitis prevalence in Amerindians living in rural areas, so a high proportion of this group was included in the study. A major limitation of the study was the type of sampling. Consecutive sampling was used due to impossibility to conduct probability sampling in this study and since the method is very cost- and time-effective. However, it is not possible to generalize the results of the survey to the entire population and there is the possibility of under- or over-representation of the population.

\section{Conclusions}

Overall low prevalence of $\mathrm{HBV}$ and $\mathrm{HCV}$ infection was found in the population studied, but higher $\mathrm{HBV}$ and $\mathrm{HCV}$ prevalence was observed among Amerindians compared to the urban population, likely due to inadequate access to prevention or treatment services due to rural or remote location. Moreover, anti-delta antibodies were found only among Amerindians from the Eastern Amazon, suggesting a risk for infection in this population. Of note is that nearly half of Amerindians had no anti-HBs, indicating the need for HBV vaccination campaigns in this population. These findings should serve as an important baseline for future primary prevention and therapeutic intervention strategies.

\section{Abbreviations}

Anti-HBc lgM: Antibodies directed against the core antigen lgM; Anti-HBc total: Antibodies directed against the core antigen; Anti-HBe: Antibodies against HBeAg; Anti-HBs: Antibodies directed against hepatitis B surface antigen; Anti-HCV: Antibodies directed against hepatitis C virus; AntiHDV: Antibodies directed against hepatitis D virus;

ECLIA: Electrochemiluminescence; ELISA: Enzyme immunoassay; HBeAg: HBV "e" antigen; HBsAg: Surface antigen of the hepatitis B virus; HBV: Hepatitis B virus; HCV: Hepatitis C virus; HDV: Hepatitis D virus; IBGE: Brazilian Institute of Geography and Statistics

\section{Acknowledgements \\ The authors wish to thank Juliana Custódio Miguel, Elisangela Ferreira da Silva, Vanessa Alves Marques and Moyra Machado Portilho for assistance in blood analysis and Tocantins Health Secretary for the assistance in blood sample collection.}

\section{Funding}

This research was supported by the Fundação de Amparo a Pesquisa do Estado do Rio de Janeiro (FAPERJ), Brazilian National Counsel of Technological and Scientific Development (CNPq) and the Oswaldo Cruz Foundation (FIOCRUZ). They had no role in designing the study and collection, analysis, and interpretation of data and in writing the manuscript. 


\section{Availability of data and materials}

The datasets generated and/or analyzed during the current study are not publicly available to maintain the privacy and confidentiality of the subjects but are available from the corresponding author on reasonable request.

\section{Authors' contributions}

LMV and VSP conceived the study; LMV, VSP, FAPM and EL designed the study protocol; HMC, LPS, LMV, VSP, FAPM carried out subject selection and recruitment; HMC, LPS, VSP, LMV performed the tests, analysis and interpretation of these data; ARR, RG, MAFMM performed spatial representation of HBV prevalence; LMV and VSP drafted the manuscript; ARR, RG, MAFMM, FAPM, VSP, LMV, EL critically revised the manuscript for intellectual content. All authors read and approved the final manuscript.

\section{Ethics approval and consent to participate}

This study was conducted in accordance with the ethical principles stated in the Helsinki Declaration. This study was reviewed and approved by Fiocruz ethics Committee and Brazilian National Ethics Council under the number of CAAE 32789914.6.0000.5248.

All participants were given a verbal explanation of the objectives and methodology of the research and were included in the study only after obtaining written signed informed consent. Parent or guardian gave written signed informed consent on behalf of any participants under the age of 18 .

\section{Consent for publication}

Not applicable.

\section{Competing interests}

The authors declare that they have no competing interests.

\section{Publisher's Note}

Springer Nature remains neutral with regard to jurisdictional claims in published maps and institutional affiliations.

\section{Author details}

'Laboratory of Viral Hepatitis, Oswaldo Cruz Institute, FIOCRUZ, Helio and Peggy Pereira Pavillion - Ground Floor - Room B09, FIOCRUZ Av. Brasil, 4365 - Manguinhos -, Rio de Janeiro, RJ 210360-040, Brazil. ${ }^{2}$ Federal University of Tocantins, Tocantins, Brazil. ${ }^{3}$ Laboratory of Information in Health, Institute of Communication and technological and scientific information in Health (ICICT), FIOCRUZ, Rio de Janeiro, Brazil. ${ }^{4}$ Molecular Virology Laboratory, Oswaldo Cruz Institute, FIOCRUZ, Rio de Janeiro, Brazil.

Received: 8 November 2017 Accepted: 30 July 2018

Published online: 20 August 2018

\section{References}

1. World Health Organization. Hepatitis B. 2017. http://www.who.int/ mediacentre/factsheets/fs204/en/. Accessed 26 Oct 2017.

2. World Health Organization. Hepatitis C. 2017. http://www.who.int/ mediacentre/factsheets/fs164/en/. Accessed 26 Oct 2017.

3. World Health Organization. Hepatitis D. 2017. http://www.who.int/ mediacentre/factsheets/hepatitis-d/en/. Accessed 26 Oct 2017.

4. Ximenes RA, Fiqueiredo GM, Cardoso MR, Stein AT, Moreira RC, Coral G, Crespo D, Dos Santos AA, Montarroyos UR, Braga MC, Pereira LM, Hepatitis Study Group. Population-based multicentric survey of hepatitis $B$ infection and risk factors in the north, south, and southeast regions of Brazil, 10-20 years after the beginning of vaccination. Am J Trop Med Hyg. 2015;93(6):1341-8.

5. Pereira LM, Martelli CM, Moreira RC, Merchan-Hamman E, Stein AT, Cardoso MR, et al. Prevalence and risk factors of hepatitis C virus infection in Brazil, 2005 through 2009: a cross-sectional study. BMC Infect Dis. 2013;13:60.

6. Brazilian Health Ministry. Epidemiological bulletin of viral hepatitis 2017. http://www.aids.gov.br/pt-br/pub/2017/boletim-epidemiologico-dehepatites-virais-2017. Accessed 26 Oct 2017.

7. Braga WS. Hepatitis $B$ and $D$ virus infection within Amerindians ethnic groups in the Brazilian Amazon: epidemiological aspects. Rev Soc Bras Med Trop. 2004;37(Suppl 2):9-13.

8. Bensabath G, Hadler SC, Soares MCP, Fields H, Dias LB, Popper H, et al. Hepatitis Delta virus infection and Labrea hepatitis. Prevalence and role in fulminant hepatitis in the Amazon basin. JAMA. 1987;258:479-83.
9. da Fonseca JC, Brasil LM. Hepatitis C virus infection in the Amazon Brazilian region. Rev Soc Bras Med Trop. 2004;37(Suppl 2):1-8.

10. Santos Cruz M, Andrade T, Bastos Fl, Leal E, Bertoni N, Villar LM, et al. Key drug use, health and socio-economic characteristics of young crack users in two Brazilian cities. Int J Drug Policy. 2013;24:432-8.

11. Villar LM, de Paula VS, de Almeida AJ, do Ó KM, Miguel JC, Lampe E. Knowledge and prevalence of viral hepatitis among beauticians. J Med Virol. 2014;86:1515-21.

12. Villar LM, Ó KM, Scalioni LP, Cruz HM, Portilho MM, Mendonça AC, et al. Prevalence of hepatitis $B$ and $C$ virus infections among military personnel. Braz J Infect Dis. 2015;19:285-90.

13. Brazilian Geographic and Statistics Institute. IBGE. Indigenous in the 2010 population census. http://indigenas.ibge.gov.br/images/indigenas/estudos/ indigena_censo2010.pdf. Accessed 26 Oct 2017.

14. Soares MC, Menezes RC, Martins SJ, Bensabath G. Epidemiology of hepatitis $B, C$ and $D$ viruses among indigenous Parakanã tribe in the eastern Brazilian Amazon region. Bol Oficina Sanit Panam. 1994;117:124-35.

15. de Paula VS, Arruda ME, Vitral CL, Gaspar AM. Seroprevalence of viral hepatitis in riverine communities from the western region of the Brazilian Amazon Basin. Mem Inst Oswaldo Cruz. 2001;96:1123-8.

16. Tavares-Neto J, Almeida D, Soares MC, Uchoa R, Viana S, Darub R, et al. Seroprevalence of hepatitis $B$ and $C$ in the western Brazilian Amazon region (Rio Branco, acre): a pilot study carried out during a hepatitis B vaccination program. Braz J Infect Dis. 2004;8:133-9.

17. Viana S, Paraná R, Moreira RC, Compri AP, Macedo V. High prevalence of hepatitis B virus and hepatitis D virus in the western Brazilian Amazon. Am J Trop Med Hyg. 2005;73:808-14.

18. Dias AL, Oliveira CM, Castilho Mda C, Silva Mdo S, Braga WS. Molecular characterization of the hepatitis $B$ virus in autochthonous and endogenous populations in the western Brazilian Amazon. Rev Soc Bras Med Trop. 2012; 45:9-12.

19. da Costa CA, Kimura LO. Molecular epidemiology of hepatitis B virus among the indigenous population of the Curuçá and Itaquaí rivers, Javari Valley, state of Amazonas, Brazil. Rev Soc Bras Med Trop. 2012;45:457-62.

20. Vieira Gde D, Ventura CG, de Sousa CM. Occurrence and spatial distribution of hepatitis $\mathrm{C}$ in a western Brazilian Amazon state. Arq Gastroenterol. 2014; 51:316-9.

21. Castilho Mda C, Oliveira CM, Gimaque JB, Leão JD, Braga WS. Epidemiology and molecular characterization of hepatitis B virus infection in isolated villages in the western Brazilian Amazon. Am J Trop Med Hyg. 2012;87:768-74.

22. Azevedo RA, Silva AE, Ferraz ML, Marcopito LF, Baruzzi RG. Prevalence of serologic markers of hepatitis $B$ and $D$ viruses in children of the Caiabi and Txucarramãe tribes from the Indian reservation of Xingu, Central Brazil. Rev Soc Bras Med Trop. 1996;29:431-9.

23. El Khouri M, Cordeiro Q, Luz DA, Duarte LS, Gama ME, Corbett CE. Endemic hepatitis $B$ and $C$ virus infection in a Brazilian eastern Amazon region. Arq Gastroenterol. 2010:47:35-41.

24. Souza KP, Luz JA, Teles SA, Carneiro MA, Oliveira LA, Gomes AS, et al. Hepatitis B and C in the hemodialysis unit of Tocantins, Brazil: serological and molecular profiles. Mem Inst Oswaldo Cruz. 2003;98:599-603.

25. Nunes HM, Monteiro MR, Soares MC. Prevalence of hepatitis B and D serological markers in the Parakanã, Apyterewa Indian reservation, Pará state, Brazil. Cad Saude Publica. 2007:23:2756-66.

26. Brabin $L$, Brabin BJ. Cultural factors and transmission of hepatitis B virus. Am J Epidemiol. 1985:122:725-30.

27. Coimbra CEA, Santos RV, Yoshida CFY, Baptista ML, Flowers NM, Valle ACF. Hepatitis B epidemiology and cultural practices in amerindian populations of Amazonia: the Tupí-Mondé and Xavante from Brasil. Soc Sci Med. 1996; 42:1735-43.

28. Ferreira A, Greca D, Tavares E, Moriya Y, Spelling F, Boeira M, et al. Seroepidemiology of hepatitis $B$ and $C$ in Kaingang Indians in the south of Brazil. Rev Panam Salud Publica. 2006;20:230-5.

29. Cruz HM, de Paula VS, Villar LM. A cross-sectional study of viral hepatitis perception among residents from southeast and north regions of Brazil. Int J Environ Res Public Health. 2018;15(2):189.

30. Brazilian Health Ministry. Ordinance $n .^{\circ} 1,489$, July 19, 2013. http://bvsms. saude.gov.br/bvs/saudelegis/gm/2013/prt1498_19_07_2013.html. Accessed 2 Mar 2018

31. Brazilian Health Ministry. Ordinance $n .{ }^{\circ} 1,498$, July 19, 2013. 2013. http:// bvsms.saude.gov.br/bvs/saudelegis/gm/2013/prt1498_19 07_2013.html. Acessed 2 Mar 2018 
32. Aquino JA, Pegado KA, Barros LP, Machado LF. Seroprevalence of hepatitis B virus and hepatitis $C$ virus infections among individuals in the state of Pará. Rev Soc Bras Med Trop. 2008;41:334-7.

33. de Almeida MK, Dos Santos KN, Fecury AA, de Oliveira CS, Freitas AS, Quaresma JA, et al. Prevalence of viral hepatitis B and C in riverside communities of the Tucuruí dam, Pará, Brazil. J Med Virol. 2012;84:1907-12.

34. Oliveira CS, Silva AV, Dos Santos KN, Fecury AA, Almeida MK, Fernandes AP, Costa CA, Freitas AS, Corvelo TC, Martins LC. Hepatitis B and C virus infection among Brazilian Amazon riparians. Rev Soc Bras Med Trop. 2011; 44(5):546-50.

35. Valois RC, Maradei-Pereira LM, Crescente JÂ, Oliveira-Filho AB, Lemos JA. HCV infection through perforating and cutting material among candidates for blood donation in Belém, Brazilian Amazon. Rev Inst Med Trop Sao Paulo. 2014;56(6):511-5.

36. Barroso LSL. Indigenous people of Tocantins. 2016. http://www.palmas.org/ tocantinsindios.htm. Accessed 30 June 2016.

Ready to submit your research? Choose BMC and benefit from:

- fast, convenient online submission

- thorough peer review by experienced researchers in your field

- rapid publication on acceptance

- support for research data, including large and complex data types

- gold Open Access which fosters wider collaboration and increased citations

- maximum visibility for your research: over $100 \mathrm{M}$ website views per year

At $\mathrm{BMC}$, research is always in progress.

Learn more biomedcentral.com/submissions 